\title{
Critical English Foreign Language Teacher Education in China
}

\author{
Ru Shang, Salah Troudi \\ Graduate School of Education, University of Exeter, Heavitree Road, EX1 2LU, Exeter, England \\ Email: rs576@exeter.ac.uk
}

\begin{abstract}
This paper is an attempt to address two distinct approaches to English language teacher education in China. The first represents an established mainstream approach to teacher development which reflects the central role of linguistic and communicative elements within teacher knowledge. This approach is often characterised by a focus on communicative pedagogy, social interaction, language proficiency, standardisation, and language curricula that aspire to strike a balance between language and communication. The second approach, still in its infancy, espouses principles of critical language education and critical pedagogy in developing teacher education programmes. This approach stresses the centrality of the humanistic element of education. It aims to raise teachers' awareness about the importance of relating content and classroom pedagogy to macro social issues beyond the boundary of the classroom. The paper will also consider the feasibility and challenges of adopting such a critical approach to English language teacher education in China.
\end{abstract}

Keywords: English language teaching, teacher education, critical approach, critical pedagogy

\section{Introduction}

The last decade has seen a massive increase in the number of Chinese people interested in learning English. According to Seargeant (2012), there are as many as 350 million leaners of English in China, a number which is close to that of the total of speakers of English as first language. This increasing interest in English in China can be seen as one of the effects of the phenomenon of globalisation and the political and economic interests of China in being a major player in world affairs. China's role in the World Trade Organisation and participation and hosting of major different world events such as the Beijing's Olympics of 2008 are examples of its new projected international image. English is seen as a major tool towards the achievement of this role (Zhu, 2003; Hu, 2005; Pan \& Block, 2011). This colossal number of English learners gives rise to considerable challenges for the English teacher education system. Educational and pedagogical approaches to English teaching and learning are also part of the challenge (Gu \& Wu, 2014). Ancient Chinese culture is often considered to be behind an obedient or a reticent role for students and an autocratic image for teachers. This legacy is still largely retained in China (Boyle, 2000). To address these challenges, the government has recently stipulated two potent strategies for teacher development: one is the 'National School Teacher Development Plan', which is an in-service training program, benefiting 1.5 million teachers (MOE China, 2011a); the other is a system of professional standards for teachers in different levels including kindergarten, primary and secondary school teachers (MOE China, 2011b). In addition to these, the trial version of English Curriculum Standards was released in 2001 as national guidance for English teaching (MOE China, 2001). A critical view of language education rests on the premise that teachers are 'thinking citizens' with their own beliefs and values (Johnston, 1999), rather than only a conduit for the transmission of knowledge to students (Shor, 1992, as cited in Crookes, 2013). Thus, we need to revisit the language teaching and language teacher education from a sociocultural and political perspectives by utilizing critical pedagogy, which may facilitate the development of foreign language teacher education (Freeman, 2004), leading to more productive outcomes for social justice (Hawkins \& Norton, 2009). This paper presents a synthesis of mainstream and critical approaches and to English language teacher education and offers a critical alternative to be considered for the Chinese context. 


\section{Mainstream English Foreign Language Teacher Education}

Compared to general teacher education, second or foreign language teacher education in China is relatively in its infancy, albeit it has developed rapidly in recent years (Day, 1991). Some of the common practices are a wide range of short-term teacher training programs and relatively long-term educational projects. The latter often last one semester or a whole academic year spread out over weekends. These programmes are provided by teacher development organizations affiliated with local educational bureaus or by universities.

Whether preservice or in-service English foreign language teacher education (EFLTE), teachers' knowledge-base remains a fundamental issue, which has dictated the content of most of FLTE programmes $(\mathrm{Gu} \& \mathrm{Wu}, 2014)$. It typically derives from "linguistics and language learning theory, and a practical component, based on language teaching methodology and opportunity for practice teaching" (Richards, 1990, p.3). The major debate over the knowledge-base of EFLTE, was for some time addressed by distinguishing between teacher training and teacher development (Johnson, 2009). The former refers to the teaching skills learned for teacher entry-level qualification; while the latter is concerned with the learning of academic theories for teacher professional development, where practical knowledge is always under-represented (Burns \& Richards, 2009). With respect to the relationship between theory and practice, Malderez and Medgyes (1996) assert that if the whole sphere of teaching can be pictured as an iceberg, where the visible part is teaching practice and the submerged part is the theory, the dividing line between teaching practice and theory is arbitrary. Additionally, Burns and Richards (2009) indicate that currently the knowledge-base of FLTE is reconstructed through the reconsideration of the nature of teacher learning rather than through the contrast between teacher training and teacher development.

\subsection{Mainstream Models of English Foreign Language Teacher Education}

Three models of teacher education are summarized by Wallace (1991): the craft model, the applied science model and the reflective model, all of which could be located within mainstream general teacher education and language teacher education (Richards, 2008). In the craft model, teacher learning is regarded as the process of imitation (Barduhn \& Johnson, 2009). Trainees just do what their teachers do without questioning the skills they learnt. Since this static learning mode solely focuses on practical skills, it is difficult for it to cope with the rapid growth of the field of language teaching.

Other models will also be considered. In the applied science model, teacher-learning is merely regarded as a cognitive activity, with an assumption that the application of empirical findings is beneficial to classroom practices (Wallace, 1991). This naturally leads to the content of FLTE mainly involving research-driven academic content and methodology courses (Richards, 2008), and a 'top-down' method conducted by outside experts who keep away from the classroom, where trainees act as voiceless and passive learners (Diamond, 1993). Also, in this model, delivery is synonymous with training, by which student teachers learn to teach, in that it is presumed that teachers' actions determine students' learning and the outcomes of teaching can be examined by the achievement of students' learning (Freeman, 2002). This process-product dualism, further legitimizes discrete and decontextualized teaching skills as well as theoretical knowledge as the knowledge-base of EFLTE (Freeman \& Johnson, 1998), giving rise to "the competency- or performance-based teacher education" (Richards, 1990, p.7), as 'technical rationality', where "predetermined, pre-selected and pre-sequenced bodies of knowledge" (Kumaravadivelu, 2012, p.8) are imparted as a guarantee of successful teaching, thereby encouraging trainees to accept a reductionist view of teaching practices and remain 'learning impoverished' in their professional development (Rosenholtz, 1989; Murray, 2009). The application of skills and theories learned in the educational programmes is up to trainees, as this model is invariably separated from their practice (Wallace, 1991). However, transforming theories and models into the real pedagogical contexts is not easy, since teaching environments are often complex (Freeman \& Richards, 1993; Freeman \& Johnson, 2004), and teachers need to make independent decisions according to different circumstances (Furlong \& Maynard, 1995). In this case, teachers' own beliefs and prior knowledge significantly influence their teaching and understanding of teaching (Richards, 1998). 
In the reflective model, teacher learning is treated as a complex mental process (Richards, 2008; Freeman, 2002) encompassing personal engagement and working context (Richards, 1998). Schön (1983) divides reflection into two types: 'reflection-in-action' and 'reflection-on-action'. The former is a spontaneous and almost unconscious action to reshape practices in order to make them more effective, without affecting the flow of teaching. It is largely dependent on tacit knowledge, thereby being difficult to spell out. The latter is to invoke theories or intelligence underlying the practice deliberately and consciously after the teaching process by analysing and evaluating actions. Reflection plays an essential role in teacher education since it helps teachers to move beyond their routine jobs (Richards, 1998). Through reflection, teacher learning has transferred the focus from how to translate the theories into practice, to personalized theorization (Burns \& Richards, 2009), thus making student teachers both recipients and creators of knowledge in their learning (Johnson, 2006), which is very fundamental for EFLTE (Freeman, 2002). As Argyris and Schon (1975) mentioned, in essence, two types of theories are exploited in teachers' working contexts: one is established theories and teaching skills in the textbooks, whereas the other is teachers' own theories or ideas drawn from their teaching practices (as cited in Harrison, 2008). These are similar to the two conceptions of 'professional knowledge' categorized by Wallace (1991), including 'received knowledge' referring to theoretical and technical knowledge accepted without question in the process of teacher learning, and 'experiential knowledge' which is developed by practice, reflection and observation, but here the observation is distinct from that in the craft model which is solely for the purpose of imitation. These concepts form a fresh view of teacher learning, which encourages exploration and internalization rather than imitation or rote memorization, and negotiation with others rather than transmission by educators (Dymoke, 2008). This in turn leads to the sociocultural turn of EFLTE (Johnson, 2006), which seeks the hidden dimension of teaching and regards teacher learning as a social process (Burns \& Richards, 2009). From a sociocultural perspective, reflection is not an individual concern but rather a social activity (Harrison, 2008), which requires student teachers to exchange alternative methods of teaching, and to reflect again on their practice (Little, 1990). In interaction with teachers of different levels of expertise, outside experts or their educators in the community of practice, they have to convert their tacit knowledge into explicit as well as understandable knowledge. This enhances trainees' reflection on their teaching as it allows them to synthesize divergent opinions and measure their own reflection. In addition, the reflective model caters for another focus of teacher learning from sociocultural perspective which is the learning context. EFLTE must be understood as situated since the contexts where trainees work shape their teaching and learning (Johnson, 2000). Collective reflection in the trainees' workplace offers learners in-time assistance from their mentors or experienced teachers through collaboration to develop new knowledge relevant to their classroom teaching (Tsui, 2009). This kind of learning is more likely to produce substantial questions arising from their teaching practice and leading to praxis (Johnson, 2006). Through negotiation among teachers practical knowledge can metamorphose into shared public property leading to the schools being transformed into places where teachers are not passive learners or trainees but active constructors of knowledge (Wood, 2007). The reflective model is a bottom-up training approach which accelerates on-going teacher development and emphasises the role of participation and co-construction in teacher learning (Richards, 2008).

Another set of EFLTE models, grounded in pre-service education in this instance, is described by Day (1991), namely the apprentice-expert model, the rationalist model, the case studies model and the integrative model. Amongst them, the apprentice-expert model aligns with the craft model, and the rationalist model is in accordance with the applied science model; the case studies model, stemming from law and business education, induces teacher learning through discussion and analysing real class scenarios. The fourth one is the integrative model which ensures that teachers can obtain all kinds of knowledge through diverse activities, yet reflective practice is the indispensable component in this model. Although Day (1991) states that the case studies model tends to only pay attention to pedagogic content knowledge in a limited fashion, we argue that, in this model, reflective practice is more likely to occur when student teachers analyse and critique their class behavior. Meanwhile, in the integrative model, Day claims that EFLTE should include all training models. This seems too demanding to be feasible since each teacher education program embraces its philosophy (Freeman \& Richards, 1993). In addition to these Zahorik's (1986) teaching conceptions echo different models of EFLTE concerned previously namely, science-research, theory-philosophy and art-craft teaching. Science-research teaching supports the applied science and rationalist model; theory-philosophy teaching mode focuses on not only 
on academic theories but also on teachers' values as well as beliefs, providing guidance in choosing appropriate teaching methods which emphasise that teaching is value-laden. The art-craft concept places emphasis on teachers' personality and self-construction of teaching knowledge, which is similar to the reflective model, but it only attends to individuality rather than collegiality in teacher teaching and learning. Freeman and Richards (1993) further point out three positions of EFLTE based on these three teaching assumptions, including noncompatible, eclecticist and developmental views. The noncompatible view in EFLTE asserts that the three models cannot be combined in one teacher education programme, whereas the eclecticist position proposes that it is advisable that a wide variety of teaching methodologies are passed on and then trainees choose the methodologies by their own preferences, values and beliefs. This has a tendency towards the postmethod pedagogy, but ignores the reality of teaching and the limitations of teachers' professional competencies as well as social identity (Akbari, 2008). The last one is the developmental position which assumes that different teaching methodologies are beneficial to the teachers at different developmental stages; thus, the science-research method seems to be suitable for novices while the theory-philosophy and art-craft methods better fit experienced teachers as both demand the understanding of practices. On the whole, Freeman (2002) presumes that "teacher education must serve two functions. It must teach the skills of reflectivity and it must provide the discourse and vocabulary that can serve participants in renaming their experience" (p.11). This shows that reflective practice and teacher learners' voice appear to be more essential in EFLTE. Nevertheless, in essence, we cannot confirm which model or teaching methodology in EFLTE is more effective and efficient than others without specifically considering contexts (Arikan, 2006).

\subsection{Mainstream English Foreign Language Teacher Education in China}

In China preservice and in-service FLTE are generally insulated from each other and little research has concentrated on the link between them (Ding, 2001). Regarding the preservice education of EFLTE, it invariably takes place in universities with three or four years' studying for certification. The content of learning is mostly related to language or language learning theories and teaching methodologies, isolated from teaching practice and school contexts (Leavitt, 1991), which is the typical applied-science model. Elsewhere, the practicum is an essential part of preservice education; it always takes place in the first term of the last academic year for a period of seven to eight weeks in primary, secondary or high schools, conducted by the craft 'apprenticeship' mode (Li, 1999), which often does not enhance reflective learning and collaborative decision-making (Taylor, Borys \& LaRocque, 1992). In terms of in-service education, it is operationalized at national, regional and institutional levels ( $\mathrm{Gu} \& \mathrm{Wu}, 2014)$. However, local educational bureaus under the national Ministry of Education have mainly adopted the applied science model to provide practical methodologies and effective technical skills suggested by outside experts $(\mathrm{Hu}, 2005)$. However, some progress has been made in employing the reflective model and school-based research, while terms such as the community of practice and action research have become familiar among teachers (GU \& Wu, 2014). Nonetheless, more extensive research is needed into schoolbased training and the reflective model since teacher professional development is not merely for individual professional enhancement but also for school development. Schools are the vital environment for this teacher development which can only be maximized when a collegial and non-threatening culture is created (Hargreaves, 1994).

Outside of China, notwithstanding some exceptions, the transmission approach or the applied science model is also still entrenched in traditional EFLTE (Freeman, 2002; Kumaravadivelu, 2012). It advocates behavourism which ignores the complexity and depth of teaching (Murray, 2009), disregards teachers' capabilities as well as potentials (Akbari, 2008) and ignores trainees' real-life teaching context (Dogancay-Aktuna, 2006). It also overlooks social, cultural, political and economic realities, where the training programs take place, leading to the impossibility of teacher-learning (Coleman, 1996, cited in Kumaravadivelu, 2001). Although the reflective model greatly mitigates the shortcomings of the transmission model with emic thinking, situated learning and collective socialization, it still does not place teacher education programs in the broad sociopolitical situation, where EFLTE is embedded (Johnson,2006; Dogancay-Aktuna, 2006; Singh \& Richards, 2006). Nonetheless, we have to recognize that "language and language teaching is political and language teachers are political actors" (Crookes, 1997, p.75), as language represents diverse ideologies and creates dynamic knowledge through interaction with social, cultural and political contexts, enriching the experiences of teacher and teacher 
learners (Kumaravadivelu, 2006). In this case, this may lead EFLTE towards a 'critical' turn, where it is linked to broader social and political relationships (Pennycook, 2001).

\section{Critical Foreign Language Teacher Education}

The 'critical' view of the sociopolitical element is regarded as the macro dimension of English teaching (Pennycook, 2001). Some scholars may question the 'critical' approach of EFLTE, since they believe that the sociopolitical issues are not vital for teacher education (Johnston, 1997; Crookes \& Lehner, 1998); or some will object that it is not pragmatic due to its abstract nature (Usher \& Edwards, 1994). In the following section we provide the reasons for shifting to the 'critical' orientation in EFLTE should be analysed.

\subsection{Reasons for a Critical Approach to EFLTE}

An important reason for this 'critical' turn may be the phenomenon of globalization (Johnston, 1999), which has given rise to huge challenges for education and teacher education. Kumaravadivelu (2012) states that, with economic and cultural globalization, the lines between different nations even where disparate religious and political beliefs are held, are blurred with the result of deepening understanding and boosting the economic growth in different countries. This is also a typical phenomenon of the postmodern era, which aspires, in principle, to respect diversity and complexity instead of seeking simplicity and hegemony "by posing questions at the boundaries of ideology, power, knowledge, class, race and gender" (p.5). These new sociopolitical contexts compel us to reconsider English language teaching and teacher education, and require us to reconstruct educational systems (Dogancay-Aktuna, 2006), and see classrooms as places where the outside social and cultural world is reflected and reproduced as well as changed (Pennycook, 2000). In addition, postnationalist and postmodernist orientations forge multicultural teaching especially in contexts with heterogeneous student populations, which urges English teachers to examine teaching through cultural politics in order to better understand students (Troudi, 2005; Eacute \& Esteve, 2000). Besides, second or foreign language teaching requires a cross-cultural expertise which reflects international powers and political connections (Crookes, 1997).

In addition to these, postmodernism considers individual identity as a continual self-social construction influenced by ability and willingness rather than by external and ideological imposition, such as history and power. For example, in the competition for jobs between native and non-native speaking teachers, the latter are marginalized owing to their linguistic background. Nevertheless, it is essential for English teachers, to create a sense of professional expertise in their own working contexts (Johnston, 1997). Considering the colonial legacy of the language, the post-colonial perspective challenges linguistic colonialism (Pennycook, 1998) and linguistic imperialism (Phillipson, 1992) by emphasising the role of linguistic and cultural sensitivities. To this end, Kumaravadivelu (2003b, 2012) further points out that there are four overlapping dimensions which can contribute to the complexities associated with discourses of colonialism and cultural sensitivity: scholastic, linguistic, cultural and economic. The scholastic aspect is often characterised by the belittling of local knowledge by propagating Western knowledge, hence English teachers may unconsciously act as 'imperial troopers' (Edge, 2003) through spreading Western ideologies in the process of English teaching. Meanwhile, the linguistic dimension tends to isolate local languages from English learning and teaching. SkutnabbKangas (2000) indicates that if minority children are taught through the medium of a dominant language at the cost of their own mother tongue, this will accelerate linguistic genocide and threaten cultural diversity (Phillipson, 1999). As foreign or second language teachers of English, we are obliged to recognize this. Meanwhile, the cultural aspect is about promoting cultural assimilation by disseminating western cultures in the process of English teaching rather than empowerment (Pennycook, 1990b). Since language is taught through ideologies, cultures, intentions and assumptions, if language teachers never guide students to deconstruct the language so as to dig out what power it serves or what real meanings it conveys, language learners may accept it as normal and right (Norton \& Hawkins, 2009). This will reinforce and reproduce inequality of social relationships in teacher-leaners' own classrooms (Pennycook, 2000). Lastly, the economic dimensions embody injustice in job hiring and economic development for Non-English speakers or Non-English speaking countries, as English has become "a gatekeeper to better 
jobs and professional opportunities in places where it was just a foreign language" (Troudi, 2005, p.120). In many places, including China, 'native-speaker-ness' continues to be a criterion in job advertisements (Reis, 2011).

Apart from globalization, another factor behind a possible move to a critical approach is the view of that " a teacher must necessarily be a political creature and ... without proselytizing, it is possible to integrate one's personal political beliefs into one's pedagogy" (Johnston, 1999, p.558) and if teacher educators are not aware of the influence of their own beliefs, it may exert a negative impact on their students' views of social issues, which may result in bias and injustice in society. Thus, language teachers play a key role in resolving educational inequity through language teaching pedagogy where ideology, culture and identity are interwoven (Hawkins, 2004; Hawkins \& Norton, 2009). A critical approach to teacher education will engage teachers in "the critical appraisal of their social roles and responsibilities and lead to socio-culturally and politically contextualized pedagogical decisions" (Dogancay-Aktuna, 2006, p.289). This approach should therefore empower and transform teachers so as to address social and political justice as part of their pedagogical content. Through such a 'critical' perspective it would be possible to raise learners' awareness of different social issues.

\subsection{Features of Critical Foreign Language Teacher Education}

Even though critical language teacher education is not commonly mentioned in research (Hawkins \& Norton, 2009), it is essential to pay more attention to it. In order to fulfil this 'critical' turn in EFLTE, we would contend that critical pedagogy is an appropriate alternative, since it argues the belief that individual teachers can be empowered to change situations by problematizing previously unquestioned practices (Johnston, 1999) and it is a politically committed approach to teaching and curriculum construction through critiquing social theory (Crook \& Lehner, 1998) by exposing social discriminatory roots and reshaping them in order to involve the people who are marginalized on the basis of gender, race or social classes (Giroux, 1983). Then teachers can understand as well as strive to change educational and social systems for social justice (Pennycook, 1990b, 1999; Widdowson, 2003). Through critical pedagogy, teacher educators are empowered to make socio-politically contextual pedagogy decisions to create a better teacher educational system, benefiting both teacher educators and student teachers (Dogancay-Aktuna, 2008). Furthermore, critical pedagogy is related to postmodernism (Johnston, 1999) with the nature of power (Freeman, 2002), where diversity is embraced, dominance is challenged and alternative expression is demanded (Johnston, 1999). Therefore, in postmodernism, "there is no best method" because of the contextual factor which is significant for pedagogical decisions (Prabhu, 1990, p.161) based on a macrostrategic framework (Kumaravadivela, 2001, 2003a, 2003b); and method is not neutral as applied by vested interests leading to social inequality (Freire, 1972; Pennycook, 1989). In this case, ready-made and prescriptive methods through a transmission approach are more likely to make student teachers dissatisfied with teacher education programs, in that it creates a conspicuous dichotomy between teachers as knowledge consumers and the experts as knowledge producers (Kumaravadivelu, 2003b, 2012). This dichotomy disregards student teachers' voice and visions of teaching so that they seldom question the established methods or pedagogies gained from teacher education programs (Kumaravadivelu, 2012).

In a postmethod era, the focus of EFLTE is on how to develop teachers' qualifications, catering for the pedagogical and social responsibilities that they should take up (Akabari, 2008) as social activists (Hawkins \& Norton, 2009). However, Kumaravadivelu (2005) asserts that there are two obstacles to postmethod pedagogy in EFLTE: one is pedagogical barriers, which mainly arise from transmission of teaching methods; the other is ideological barriers, regarding power representations and what constitutes valid knowledge. Even though Kumaravadivelu does not come up with specific strategies for overcoming these obstacles, he puts forward three 'operating principles' for language teacher education in a postmethod condition or postmodernism. These are particularity, practicality, and possibility (2001, 2003, 2006a, 2006b, 2012). Particularity centers on local contexts by 'situated understanding' of a holistic picture in particular situations, where teacher education is embedded and sensitive to these local contexts. Otherwise, teacher education programs will be futile. Practicality advocates feasibility for teachers to generate their theories and "to practise what they theorize" (2006b, p.69). The responsibility of teacher education is therefore not only the maximizing of learning opportunities "but also a means for understanding and transforming learner and teacher possibilities in and outside the classroom" 
(Kumaravadivelu, 2012, p.14). Possibility focuses on the formation of personal and social identity through raising sociopolitical awareness, which induces student teachers to transcend the constraints imposed by power representations.

Hawkins and Norton (2009) point out that critical practices in language teacher education can promote "critical awareness, critical self-reflection, and critical pedagogical relations" (p.33). First and foremost, raising critical awareness means that teacher educators enhance teacher-learners' sociopolitical awareness by making inequitable relationships of power in society and teacher communities visible in their teaching. Second, some practical strategies for promoting student teachers' critical self-reflection are suggested, in the way that student teachers reflect on their own positions and identities to seek possibilities for social transformation. Third, critical pedagogical relationships espouse equal relations between teacher educators and student learners through not only modelling but also encouraging teacher-learners to devise some pragmatic approaches to provide their own learners with equal opportunities.

Based on these practical strategies for critical teacher education and critical pedagogy, we would argue that there are two main features of critical EFLTE, namely empowerment and transformation which are interrelated and interdependent. In other words, both teacher educators and student teachers are empowered through critical pedagogy in teacher education programs, and then they achieve the possibilities associated with particularity and practicality, to transform inequity and question the givens in their teaching and society within the broader sociopolitical context (Pennycook, 2000, 2001). To begin with, autonomy is a seminal part of the postmethod condition and critical pedagogy (Kumaravadivelu, 2001, 2003b). In critical EFLTE, autonomous learners are equipped with academic, social and liberatory autonomy: academic autonomy boosts teachers to become effective learners with a wide variety of learning strategies while social autonomy makes learners more collaborative in their learning communities (Kumaravadivelu, 2001). Liberatory autonomy is essential to empower learners to adopt critical views in the sociopolitical contexts so as to shape the environment of the foreign language classroom or overcome sociopolitical impediments, such as political oppression and social discrimination, since language classes possess more wide-ranging topics than other educational enterprises.

Teacher educators also need to hold a high degree of autonomy with concomitant competence and confidence to build their own theories and make their own pedagogic decisions. They also ought to be aware of the core values of teacher education programs (Troudi, 2005). For teachers' practical theories not to be constrained by narrow interpretations (Hargreaves, 1994), a sense of plausibility and principled pragmatism needs to be espoused. This should entail "a classroom learning [that] can be shaped and reshaped by teachers as a result of self-observation, self-analysis, and self-evaluation" (Kumaravadivelu, 2003b, p.33), of their local sociopolitical contexts. The autonomy of both teacher educator and teacher-learner renders it possible to hear their voices in teacher education programs. For example, they may determine how to design a curriculum and what knowledge is to be included (Crookes \& Lehner, 1998). Also, this autonomy is likely to enhance their participation and dialogic interaction in the process of learning and theorizing (Alexander, 1986), which in turn would lead to an equilibrium of the relations between teacher educators and teacher-learners (Freeman, 2002). However, it needs to be stressed that equitable relations between teachers and learners in critical teacher education does not mean that teacher educators have to succumb to the challenges or questions that student learners pose, but rather they need to problematize them continuously (Crookes \& Lehner, 1998). This would result in the production of more reflection on their practice. As 'transformative intellectuals' who question their practice constantly (Giroux, 1988; Pennycook, 1989, 2001) and 'critical reflective practitioners' empowered by a high level of autonomy, they are in a position to transform teachers' everyday teaching and to face wider social changes (Wallace, 1991; Bartlett, 1990). This is in sharp contrast to mainstream and consumerist teacher education where teachers are just consumers of the theories conveyed by teacher educators with the aim of mechanically translating these theories into practice. Additionally, critical pedagogues treat teachers as critical reflective practitioners and who are willing to link pedagogic concerns with the broader social issues collectively and collegially for a better human life (Giroux \& McLaren, 1989).

In this case, critical EFLTE has become not only more accessible but also inclusive. Besides, in this process, teachers also need to reflect on their identities and positions in society, which may be seen as obstacles for social transformation (Hawkins \& Norton, 2009). As an illustration, non-native speaking teachers may realize that they are multicompetent rather than 'failed native speakers' (Cook, 1992). 
Hence, critical teacher education brings about self-regulated and self-determined teacher educators and teacher-learners through empowerment, who endeavour to transcend hindrances to social justice in their sociopolitical environments.

\section{Critical Foreign Language Teacher Education in China}

In the post-method era, Murray (2009, p.17) claims that "at this time, more than ever, flexibility, adaptability and contextual awareness need to be emphasized in TESOL teacher education". As discussed earlier, it is evident that critical teacher education encompasses all these factors, as critical pedagogy centres on context-sensitivity, autonomy, empowerment as well as transformation. It advocates particularity, practicality and possibility in the process of conducting critical teacher education (Kumaravadivelu, 2012). It also aspires to encourage teachers to be critically minded intellectuals (Giroux, 2009). In China, even though a traditional country influenced by the Confucian culture where respect for teachers and authority is a social norm (Lee, 2000), there are signs of the possibility of the development of critical EFLTE. There are also some considerable challenges to be taken into consideration.

\subsection{Opportunities}

China has enacted a wide variety of policies to promote English learning in the educational system in order to accelerate globalization. For example, since September 2001, students in most primary schools start to take English from grade three as a compulsory subject (MOE, 2001a). However, recently the government became sensitive to 'English colonization', which could result in the erosion of Chinese culture (Zhou, 2007) and started to consider measures to curb this conceivable threat. In fact, an 'English language threat discussion' has become a hot topic in China (Pan \& Seargeant, 2012). Against this background, we would argue that there is an opportunity for critical teacher education, which can raise English teachers' awareness of discourses of neo-colonisation, consumerism and cultural reductionism that can be associated with the teaching of English (Block, Gray \& Holborow, 2012). Plus, the number of Chinese speaking English teachers amounts to 500,000 in China, (Bolton, 2004). If they can recognize that they are multicompetent and bilingual or multilingual teachers with the advantages of the familiarity with their own social and cultural context instead of seeing themselves as non- native speaking teachers (Braine, 1999; Jin, 2005), they are more likely to be empowered to enhance their own teaching, theorise from their practice and design their own professional development models (DogancayAktuna, 2006; Walter \& Briggs, 2012). The Chinese educational system is characterised by examoriented and teacher-centered approaches. In addition, China's large population generally leads to largeclass size in teaching. These issues seem to be hurdles to cross in providing teacher education from the critical perspective. However, it is also seen as a needed impetus for such an endeavour. Peculiar contexts and challenges in China urgently require teachers to construct their practitioners' theories through reflection and collaboration to develop context-sensitive solutions. This is instead of utilizing external knowledge generated by theorists and handed down to them in the educational programs. This calls for teacher education from a critical perspective rather than a mainstream transmission model. Thus, the unique cultural, social and political context in China renders critical teacher education necessary.

\subsection{Challenges}

Although the particularities of the Chinese cultural and sociopolitical context necessitate a critical approach, they also bring a number of challenges. In the first place, the Chinese exam-oriented educational culture curbs the autonomy of teachers and learners, since examinations are seen as scientific and fair approaches to gauge learning and teaching (Qi, 2007; Kirkpatrick \& Zang, 2011). In this case, teachers risk being regarded as unqualified or irresponsible, if they cause students' failure in examinations. Moreover, the standards for curriculum, exams and teachers' appraisal are regulated by the local or national government, which does not allocate much space for teachers' autonomy (Bartlett, 1990; Akbari, 2008), thus giving in to 'performativity' in their working contexts without reflection 
(Forde et al., 2006). In the second place, apart from the pressure of regional or national exams, the large student population makes English teachers' workload heavy due to the demands of homework correction, student evaluations and teaching preparation (Troudi, 2005). This tends to force them to conform to the curriculum and teaching methods imposed by outside experts (Crookes, 1997; Dean, 2014). With little reflection on their own teaching practices, they resort to their own past learning experiences and adopt familiar, predetermined and prescriptive methods. Therefore, they seldom problematize the givens that they obtained from their educational programs, even though some teachers do complain about the gaps between training and teaching. Finally, China is not a Western-style democratic country and the government possesses highly exclusive privileges. Even though the political structure has seen a gradual change through economic reform (Lu, 2011; Guthrie, 2012), discussing political issues is still sensitive in China. Against such background critical teacher education may face insurmountable challenges. Nonetheless, we contend that there is some space for some elements of critical teacher education, such as questioning inequity, discrimination and injustice in the educational arena, which may appeal to the government and consequently leading to pedagogical improvement.

\section{Conclusion}

In a post-modern society characterised by diversity, decentralization and instability we need to reconceptualize teacher education and EFLTE towards a 'critical' perspective to promote teachers' professional capabilities to confront future challenges. Here, 'critical' does not equal 'critical thinking'- it means that teacher education and EFLTE are redefined in the broader educational, cultural and sociopolitical context (Pennycook, 2001; Crookes \& Lehner, 1998). It implies that English teachers are not just trained as instructors to deliver content, but especially as intellectuals who hold their own beliefs, values and lived experiences with social responsibilities (Johnson, 2006; Kumaravadivelu, 2006a). A critical approach to EFLTE would stress that the relationship among teacher educators, teacherlearners and even researchers be symbiotic and sometimes synergistic rather than isolated (Kumaravadivelu, 2001). It will also seek to empower teacher educators and student teachers to theorise their own practices and engage in their own on-going professional development connected with their local sociopolitical context. Ultimately, through raising awareness and supplying critical pedagogical tools, we can create a learning environment entailing the characteristics of contextual compatibility, educational conviviality and equitable learning opportunities for teacher-learners.

\section{References}

1. Akbari, B. (2008). Postmethod Discourse and Practice. TESOL Quarterly, 42(4), 641-652.

2. Alexander, R. J. (1986). Innovation and Continuity in the Innitial Teacher Education Curriculum. In R. J. Alexander, M. Craft, \& J. Lynch (Eds.), Change in Teacher Education: Context and Provision Since Robbins (pp. 103-160). London: Holt, Rinehart, Winston.

3. Arikan, A. (2006). Postmethod Condition and Its Implications for English Language Teacher Education. Journal of Language and Linguistic Studies, 2(1), 1-11.

4. Barduhn, S., \& Johnson, J. (2009). Certification and Professional Qualifications. In A. Burns, \& J. C. Richards (Eds.), The Cambridge Guide to Second Language Teacher Education (pp. 59-65). Cambridge: Cambridge University Press.

5. Bartlett, L. (1990). Teacher Development Though Reflective Teaching. In J. C. Richards, \& D. Nunan (Eds.), Second Language Teacher Education (pp. 202-214). Cambridge: Cambridge University Press.

6. Bolton, K. (2004). World Englishes. In A. Davies, \& C. Elder (Eds.), The Handbook of Applied Linguistics (pp. 367-396). Oxford: Blackwell Publishing Ltd.

7. Boyle, J. (2000). Education for Teachers of English in China. Journal of Education for Teaching: International Research and Pedagogy, 26(2), 147-155.

8. Braine, G. (1999). From the Periphery to the centre: One Teacher's Journey. In G. Braine (Ed.), Non-native Educators in English Language Teaching (pp. 15-28). London: Routledge.

9. Burns, A., \& Richards, J. C. (2009). Introduction. In A. Burns, \& J. C. Richards (Eds.), The Cambridge Guide to Second Language Teacher Education (pp. 1-8). Cambridge: Cambridge University Press. 
10. Campbell, K. P., \& Yong, Z. (1993). The Dilemma of English Lanague Instruction in People's Republic of China. TESOL Journal, 2(4), 4-6.

11. Carr, D. (2000). Professionalism and Ethics in Teaching. London: Routledge.

12. Chang, H. C., \& Holt, G. R. (1994). A Chinese Perspective on Face as Inter-relational Concern. In S. TingToomey (Ed.), The Challenge of Facework: Cross-cultural and Interpersonal Issues (pp. 95-132). Albany: State University of New York Press.

13. Cheng, X. T. (2011). The 'English Curriculum Standards' in China: Rationales and Issues. In A. W. Feng (Ed.), English Education across Greater China (pp. 133-150). Bristol: Multilingual Matters.

14. Cheng, X., \& Sun, X. (2010). Issues and Challenges with Englsih Language Teacher Education and Professional Development in China. Foreign Language Learning Theory and Practice, 3, 1-6.

15. Cook, V. J. (1992). Evidence for Mulicompetence. Language Learning, 42(4), 557-591.

16. Crookes, G. (1997). What Influences What and How Second Language and Foreign Language Teacher Teach? The Modern Language Journal, 81(1), 67-79.

17. Crookes, G. V. (2013). Critical ELT in Action Foundations, Promises, Praxis. London: Routledge Taylor \& Francis Group.

18. Crookes, G., \& Lehner, A. (1998). Aspects of Process in an ESL Critical Pedagogy Teacher Education Course. TESOL Quarterly, 32(2), 319-328.

19. Day, R. R. (1991). Models and the Knowledge Base of Second Language Teacher Education. In E. Sadtono (Ed.), Issues in Language Teacher Education (pp. 38-48). Sigapore: Regional Language Centre.

20. Diamond, C. T. (1993). In-service Education for Somthing More: A Personal Construct Approach. In J. Janangelo, L. A. Perry, \& P. Kahaney (Eds.), Theoretical and Critical Perspectives on Teacher Change (pp. 45-66). Norwood: Ablex Publishing Corporation.

21. Ding, G. (2001). The Integration of Pre-service and In-service Teacher Education: The Cases of Shanghai and Jiangsu. Asia-Pacific Journal of Teacher Education 85 Development, 4(2), 61-72.

22. Dogancay-Aktuna, S. (2006). Expanding the Socio-Cultural Knowledge Base of TESOL Teacher Education. Language, Culture and Curriculum, 19(3), 278-295.

23. Dunkin, M. J., \& Briddle, B. J. (1974). The Study of Teaching. Oxford: Holt, Rinehart \& Winston.

24. Dymoke, S. (2008). An Overview of Learning. In S. Dymoke, \& J. Harrison (Eds.), Reflective Teaching 83 Learning (pp. 45-68). London: Sage.

25. Eacute, J., \& Esteve, M. (2000). The Transformation of the Teachers' Role at the End of the Twentieth Century: New Challenges for the Future. Educational Review, 52(2), 197-207.

26. Edge, J. (2003). Imperial Troopers and Servants of the Lord: A Vision of TESOL for the 21st Century. TESOL Quarterly, 37(4), 701-709.

27. Forde, C., McMahon, M., McPhee, A. D., \& Patrick, F. (2006). Professional Development Reflection and Euqiry. London: Sage Publication Ltd.

28. Freeman, D. (2002). The Hidden Side of the Work: Teacher Knowledge and Learning to Teach. A Perspective from North American Educational Research on Teacher Education in English Language Teaching. Language Teaching, 35(1), 1-13.

29. Freeman, D. (2004). Language, Sociocultural Theory, and L2 Teacher Education: Examining the Technology of Subject Matter and the Architecture of Instructions. In M. R. Hawkins (Ed.), Language Learning and Teacher Education: a Sociocultural Approach (pp. 169-197). Clevedon: Multilingual Matters Ltd.

30. Freeman, D., \& Johnson, K. E. (1998). Reconceptualizing the Knowledge-base of Language Teacher Education. TESOL Quarterly, 32(3), 397-417.

31. Freeman, D., \& Johnson, K. E. (2004). Comments on Robert Yaltes and Dennis Muchisky's "on Reconceptualizing Teacher Education" Readers React... Common Reconceptions about the Quiet Revolution. TESOL Quarterly, 38(1), 119-127.

32. Freeman, D., \& Richards, J. C. (1993). Conceptions of Teaching and the Education of Second Language Teachers. TESOL Quarterly, 27(2), 193-216.

33. Freire, P. (1972). Pedagogy of the Oppressed. Middlesex: Penguin Books.

34. Fullan, M., \& Hargreaves, A. (1992). Teacher Development and Educational Change. London: Routledge.

35. Furlong, J., \& Maynard, T. (1995). Mentoring Student Teachers: the Growth of Professional Knowledge. London: Routledge.

36. Giroux, H. A. (1983). Theory and Resistance in Educatio: A Pedagogy for the Opposition. South Hardley: Bergin. 
37. Giroux, H. A. (1988). Teachers as Intellectuals: Towards a Critical Pedagogy of Learning. London: Bergin \& Gravey.

38. Giroux, H. A. (2009). Teacher Education and Democratic Schooling. The Critical Pedagogy Reader, 2, 438-459.

39. GIroux, H. A., \& McLaren, P. (1989). Schooling, Cutural Politics, and the Struggle for Democracy. In H. A. Giroux, \& P. McLaren (Eds.), Critical Pedagogy, the State and the Struggle for Culture (pp. xi-xxxv). Albany, NY: SUNY.

40. Gu, Y. Q., \& Wu, Y. A. (2014). Voices from Chinese Teacher-educators. Language Teaching Research, 18(2), 146-151.

41. Guthrie, D. (2012). China and Globalization: the Social, Economic and Political Transformation of Chinese Society (3rd ed.). Oxon: Routledge.

42. Hargreaves, A. (1994). Changing Teachers, Changing Times. New York: Teacher College Press.

43. Hargreaves, D. (1994). The New Professionalism: The Synthesis of Professional and Institutional Development. Teaching \& Teacher Education, 10(4), 423-438.

44. Harrison, J. (2008). Professional Development and the Reflective Practitioner. In H. A. Giroux, \& P. McLaren (Eds.), Reflective Teaching \& Learning (pp. 7-44). London: Sage.

45. Hawkins, M. R. (2004). Language Learning and Teacher Education: A sociocultural Approach. Clevedon: Multilingual Matters Ltd.

46. Hawkins, M., \& Norton, B. (2009). Critical Language Teacher Education. In A. Burns, \& J. C. Richards (Eds.), The Cambridge Guide to Second Language Teacher Education (pp. 30-39). Cambridge: Cambridge University Press.

47. Ho, J., \& Crookall, D. (1995). Breaking with Chinese Cultural Traditions: Learner Autonomy in English Language Teaching. System, 23(2), 235-243.

48. Hu, G. W. (2005). English Language Education in China: Policies, Progress, and Problems. Language Policy, $4(1), 5-24$.

49. Jin, J. (2005). Which is Better in China, a Local or a Native-English Speaking Teacher? English Today, 21(3), $39-46$.

50. Johnson, K. E. (2000). Innovations in TESOL Teacher Education: A quiet Revolution. 1-7.

51. Johnson, K. E. (2006). The Sociocultural Turn and Its Challenges for Second Language Teacher Education. TESOL Quarterly, 40(1), 235-257.

52. Johnson, K. E. (2009). Trends in Second Language Teacher Education. In A. Burns, \& J. C. Richards (Eds.), The Cambridge Guide to Second Language Teacher Education (pp. 20-29). Cambridge: Cambridge University Press.

53. Johnston, B. (1997). Do EFL Teachers Have Careers? TESOL Quarterly, 31(4), 681-712.

54. Johnston, B. (1999). Putting Critical Pedagogy in Its Place: A Personal Account. TESOL Quarterly, 33(3), $557-565$.

55. Kirkpatrick, R., \& Zang, Y. B. (2011). The Negative Influences of Exam-Oriented Education on Chinese High School Students: Backwash from Classroom to Child. Language Testing in Asia, 1(3), 36-45.

56. Kumaravadivelu, B. (1994). The Postmethod Condition: (E)merging Strategies for Second/ Foreign Language Teaching. TESOL Quarterly, 28(1), 27-48.

57. Kumaravadivelu, B. (2001). Toward a Postmethod Pedagogy. TESOL Quarterly, 35(4), 537-560.

58. Kumaravadivelu, B. (2003a). A Postmethod Perspective on English Language Teaching. World Englishes, 22(4), 539-550.

59. Kumaravadivelu, B. (2003b). Beyond Methods: Macrostrategies for Language Teaching. New Haven and London: Yale University Press.

60. Kumaravadivelu, B. (2006a). TESOL Methods: Changing Tracks, Challenging Trends. TESOL Quarterly, 40(1), 59-81.

61. Kumaravadivelu, B. (2006b). Understanding Language Teaching: from Method to Postmethod. London: Lawrence Erlbaum Associations Publishers.

62. Kumaravadivelu, B. (2012). Language Teacher Education for a Global Society: a Modular Model for Knowing, Analyzing, Recognizing, Doing and Seeing. Oxon: Routledge.

63. Leavitt, H. B. (1991). Worldwide Issues and Problems in Teacher Education. Journal of Teacher Education, 42(5), 323-331.

64. Lee, C. (2000). Encouraging Chinese Learners Participate. Modern English Teacher, 9(1), 51-54.

65. Li, D. (1999). Modernization and Teacher Education in China. Teaching and Teacher Education, 15(2), 179192. 
66. Little, J. W. (1990). The Persistence of Privacy: Autonomy and Initiative in Teachers' Professional Relations. Teachers' College Record, 91(4), 509-536.

67. Littlewood, W. (2009). Chinese Learners and Interactive Learning: the Chinese Context. In T. CoverdaleJones, \& P. Restall (Eds.), Internationalising the University (pp. 206-222). London: Palgrave Macmillan.

68. Lu, R. C. (2011). Chinese Democracy and Elite Thinking. New York: Palgrave Macmillan.

69. Malderez, A., \& Medgyes, P. (1996). Taking Stock. In P. Medgyes, \& A. Malderez (Eds.), Changing Perspectives in Teacher Education (pp. 111-119). Oxford: Heinemann.

70. McCormick, B. L. (1990). Political Reform in Post-Mao China: Demacracy and Bureaucracy in a Leninist State. Oxford: University of California Press.

71. McIntyre, D. (1993). Theory, Theorizing and Reflection in Initial Teacher Education. In J. Calderhead, \& P. Gates (Eds.), Conceptualizing Reflection in Teacher Development (pp. 39-52). London: The Falmer Press.

72. Mellen, B. (2014). An Investigation into Perceptions of Non-native English Teachers in Shanghai about their English Teaching Role and Responsibilities in Secondary Schools. Durham: (Doctoral dissertation, Durham Universituy).

73. MOE, C. (2001). English Curriculum Standards for Compulsory Education and Senior Secondary Education. Beijing: MOE.

74. MOE, C. (2011a). National Teacher Development Plan for Primary and Secondary School Teachers. Beijing: MOE.

75. MOE, C. (2011b). Establishing Teacher Professional Standards for a Quality Teacher Force. Beijing: MOE.

76. Murray, J. (2009). Teacher Competencies in the Post-method Landscape: the Limits of Competency-based Training in TESOL Teacher Education. Research Online, 24(1), 17-29.

77. Pan, L., \& Block, D. (2011). English as a 'Global Language' in China: An Investigation into Learners' and Teachers' Language Beliefs. System, 39(3), 391-402.

78. Pan, L., \& Seargeant, P. (2012). Is English a Threat to Chinese Language and Culture? English Today, 28(3), 60-66.

79. Pennycook, A. (1989). The Concept of Method, Interested Knowledge, and the Politics of Language Teaching. TESOL Quarterly, 23(4), 589-618.

80. Pennycook, A. (1990 a). Critical Pedagogy and Second Language Education. System, 18(3), 303-314.

81. Pennycook, A. (1990 b). Towards a Critical Applied Linguistics for the 1990s. Issues in Applied Linguistics, 1(1), 8-28.

82. Pennycook, A. (1998). English and the Discourses of Colonialism. New York: Routledge.

83. Pennycook, A. (1999). Introduction: Critical Aproaches to TESOL. TESOL Quarterly, 33(3), 329-348.

84. Pennycook, A. (2000). English, Politics, Ideology from Colonial Celebration to Postcolonial Performativity. In T. Ricento (Ed.), Ideology, Politics and Language Policies: Focus on English (pp. 49-66). Amsterdam: Benjamins Publishing Company.

85. Pennycook, A. (2001). Critical Applied Linguistics: A Critical Introduction. London: Lawrance Erlbaum Associates.

86. Phillipson, R. (1999). Voice in Global English: Unheard Chords in Crystal Loud and Clear. Review of the Book English as a Global Language. Applied Linguistics, 20(2), 265-276.

87. Prabhu, N. S. (1990). There is No Best Method-Why? TESOL Quarterly, 24(2), 161-176.

88. Qi, L. (2007). Is Testing an Efficient Agent for Pedagogical Change? Examining the Intended Washback of the Writing Task in a High-stakes English Test in China. Assessment in Education, 14(1), 51-74.

89. Richards, J. C. (1990). The Dillema of Teacher Education in Second Language Teaching. In J. C. Richards, \& D. Nunan (Eds.), Second Language Teacher Education (pp. 3-15). Cambridge: Cambridge University Press.

90. Richards, J. C. (1998). Beyond Training. Cambridge: Cambridge University Press.

91. Richards, J. C. (2008). Second Language Teacher Education Today. Regional Language Centre Journal, 39(2), 158-177.

92. Rosenholtz, S. (1989). Teachers' Workplace: The Social Organization of Schools. New York: Longman.

93. Schön, D. (1983). The Reflective Practitioner: How Professionals think in Action. London: Temple Smith.

94. Scollon, R., \& Scollon, S. (1994). The Post-Confucian Confusion. Hong Kong: Hong Kong City Polytecnic University.

95. Seargeant, P. (2012). Exploring World Englishes: Language in a Global Context. Abingdon: Routledge.

96. Singh, G., \& Richards, J. C. (2006). Teaching and Learning in the Language Teacher Education Course Room: A Critical Sociocultural Perspective. Regional Language Centre Journal, 37(2), 149-175. 
97. Skutnabb-kangas, T. (2000). Linguistic Human Rights and Teachers of English. In J. K. Hall, \& W. G. Eggington (Eds.), The Sociopolitics of Englsih Language Teaching (pp. 22-44). Clevedon: Multilingual Matters.

98. Taylor, G., Borys, A., \& LaRocque, L. (1992). Reforming Teacher Education: Toward an Alternative Model of Practicum. International Journal of Teacher Reform, 1(4), 376-391.

99. Troudi, S. (2005). Critical Content and Cultural Knowledge for Teachers of English to Speakers of Other Languages. Teacher Development, 9(1), 115-129.

100. Tsui, B. M. (2009). Teaching Expertise: Approaches, Perspectives, and Characterizations. In A. Burns, \& J. C. Richards (Eds.), The Cambridge Guide to Second Language Teacher Education (pp. 190-198). Cambridge: Cambeidge University Press.

101. Usher, R., \& Edwards, R. (1994). Postmodernism and Education: Different Voices, Different Worlds. London: Routledge.

102. Wallace, M. J. (1991). Training Foreign Language Teachers: A Reflective Approach. Cambridge: Cambrisge University Press.

103. Walter, C., \& Briggs, J. (2012). What Professional Development Makes the Most Difference to Teachers? Oxford: A Report Sponsored by Oxford University Press.

104. Wood, D. R. (2007). Professional Learning Communities: Teachers, Knowledge, and Knowing. Theory Into Practice, 46(4), 281-290.

105. Zahorik, J. A. (1986). Acquiring Teaching Skills. Journal of Teacher Education, 37(2), 21-25.

106. Zhou, C. Q. (2007). Global Englishes: a Challenge for English Padagogy in China. Jounal of English as an Interbational Language, 2, 82-102.

107. Zhu, H. M. (2003). Globalization and New ELT Challenges in China. English Today, 19(4), 36-41. 